firm to install mechanically controlled machine tools and operate them for a period on approval. This project, the report points out, was undertaken at the specific request of the Ministry of Technology. Other new projects include plastic sacks for tropical produce, a new tower fermentation process, and transducer production, in collaboration with George Kent Ltd, for measuring instruments for the process control industry. That project, too, has the stamp of the Ministry of Technology. The corporation is also helping to develop microfilm equipment, and a high torque motor developed at International Research and Development in Newcastle upon Tyne. Although the report does not say so, it would be fair to guess that the motor makes use of superconducting magnets to produce a high torque at low speeds.

\section{Promotion without Obligation}

MoRE scientists working in Government establishment:s in Britain have been awarded "special merit" promotions. These promotions, awarded to scientists who have produced a very high standard of original work, enable them to continue their research work without the administrative responsibility normally associated. with their new grades. The promotions follow recommendations by a special committee which each year reviews the work of scientists doing research in Government and other public service establishments.

Of the twenty-six research workers awarded promotions this year, Mr K. C. Bowen, Dr J. Croney, Dr C. Hilsun, Dr O. Kubaschewski and Dr E. H. Mansfield have been promoted to Deputy Chief Scientific Officer. Dr G. H. Byford, Dr P. Dean, Dr A. Franks, Dr H. A. French, Dr P. H. Greenwood, Mr H. V. Hempleman, Dr J. M. Linke, Dr E. G. S. Paige, Mr P. H. Parkin, Dr E. R. Pike, Mr W. J. G. Pinsker and Mr D. E. Weston have become Senior Principal Scientific Officers and Dr J. H. Darbyshire is now a Senior Research Officer, Grade I. A number of promotions have also been made within the United Kingdom Atomic Energy Authority. Thus Dr P. G. Burke and Dr R. J. N. Phillips have become Senior Scientific Officers. In the Agricultural Research Council, Dr L. W. Mapson has been promoted to Deputy Chief Scientific Officer. Dr J. Bligh, Dr P. N. Hobson, Dr Daphne J. Osborne, Dr F. W. Robertson and Dr C. R. W. Spedding are now designated Senior Principal Scientific Officers.

\section{Sad Gas}

For an industry which has just found unexpected new wealth on its doorstep, the British gas industry is singularly long-faced. The annual report of the Gas Council (HMSO, 16s. 6d.) reveals that this year's surplus has fallen sharply from $\mathfrak{£} 11 \cdot 1$ million last year to only $\mathfrak{} 3.9$ million this year. In the days before natural gas was found beneath the North Sea, the council did much better-in 1964-65, profits were as high as $£ 15.2$ million. This year's results mean that the council has failed to maintain its running target of a return of 10.2 per cent on capital invested; the figure now stands at $9 \cdot 1$ per cent.

In fact these depressing results are understandable. The need for extensive re-equipment to cater for natural gas has combined with economic conditions to give the Gas Council a tricky year. Transitional costs have not yet justified themselves in increased revenue, and the Government-imposed standstill on prices has aggravated the situation. The council is now discussing with the Ministry of Power what its financial objectives should be over the next few years, and the report points out that future financial objectives must strike a balance between the transitional burdens in the short term and the undoubted benefits in the long term.

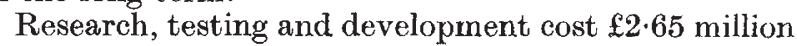
in 1966-67, the report reveals, and the area gas boards spent a further $£ 1.26$ million on development. The basic research group has been working on catalysis, adsorption and chemisorption and reaction kinetics. The conversion to natural gas has involved the development of a natural gas substitute which can be burned in the same burners during the period of conversion and for peak loads later. Several underground storage sites have been investigated for porosity, permeability and pore-size distribution, and attempts are being made to assess the risk of contamination of gas held underground by hydrogen sulphide of bacterial origin.

\section{Snags in Space}

ArIEL III, the first all-British satellite, has been a mixed success. Although all the sub-systems-power, data handling and telemetry-have worked well and show every sign of fulfilling their design life of one year, the data they have been sending back have been confused. One experiment, from the Nuffield Radio Astronomy Laboratory at Jodrell Bank, has so far yielded only interference.

There seems no doubt that the two experiments designed at the University of Birmingham are the cause of the interference. One measures electron density in space by means of a parallel plate capacitor consisting of two circular grids carried at the end of one of the solar cell paddles, and the other, attached to another paddle, measures electron temperature. Both these experiments are working well, according to Dr J. H. Wager of the University of Birmingham, who described them at a symposium organized by the Institution of Electronic and Radio Engineers on October 13. Unfortunately, both experiments interfere with the Jodrell Bank experiment, which is designed to measure absolute values of cosmic noise in space. Dr P. C. Gregory from Jodrell Bank has identified two distinct types of interference, one caused by the density probe and the other by the temperature probe. The first type is the more severe, saturating receiver output under all conditions, but the second is not quite so severe, and Dr Gregory philosophically hopes for at least some results from his experiment.

The Birmingham experiments have also upset the attempt by the Meteorological Office to measure the concentration of molecular oxygen in space. Dr P. J. L. Wildman described the experiment, in which the attenuation of the light of the Sun is studied as the satellite enters and leaves the Earth's shadow. In addition to the Birmingham interference, which in this case is not too severe, the experiment is sending back a spurious signal from the shadow side of the Earth, when it should be silent. 